\title{
Snapshot of an On-Going Trade in Reptile Wholesaler, Kebumen, Central Java: Preparation, Trading, and Conservation Implications
}

\author{
Nia Kurniawan ${ }^{1}$, Fitra Arya Nugraha ${ }^{1}$, Andri Maulidi ${ }^{1,2}$, A.S. Firdaus ${ }^{1}$, A.M. Kadafi ${ }^{1}$, Agung Sih \\ Kurnianto ${ }^{3}$ \\ ${ }^{1}$ Biology Departement, Faculty of Sciences, Brawijaya University, Malang, Indonesia \\ ${ }^{2}$ Biology Education Program, Faculty of Teacher Training and Education, Tanjungpura University, Pontianak, Indonesia \\ ${ }^{3}$ Postgraduate of Natural Resources Management, Brawijaya University, Malang, Indonesia
}

\begin{abstract}
Indonesia is known as one of the highest supplier on animal illegal trading, especially reptile. The objectives of this study are to reveal the preparation proccess of reptiles in the wholesaler and the flow of illegal trade through deep interview and observation in Kebumen Regency, Central Java, Indonesia. The results showed that wholesaler did some specific processes towards reptile. As much as 289 reptiles were observed to be traded in various conditions. Dry season affect the amount of animal sold. Chinese Ratsnake (Ptyas korros) and Reticulated Python (Malayopython reticulatis) became the most traded commodity within reptile trading, and is reported to be exported to other countries. Trafficking of adult reptiles could threaten their wild population, yet the level of exploration and monitoring toward reptile's wild population are still low.
\end{abstract}

Keywords: Kebumen, Population, Reptile, Trade, Wholesaler

\section{INTRODUCTION}

The high demand of accessories and products derived from reptiles correlates with the level of trafficking in the wild, which is on the same time, the evaluation of reptile's population and distribution is difficult to conduct [1]. In this case, wholesaler plays a vital role by distributing the captured animals to poacher, trader, and exporter in regional and national level. On the other side, wholesaler can be an information resources in a local scale [2].

Indonesia, as one of the biggest country in illegal trading and exporting products derivated from reptiles, receives an enormous economic benefits from trading activities [1]. On the other hand, Indonesia has been registered in CITES (Convention on International Trade in Endangered Species of Wild Fauna and Flora) treaty which regulates the export of endangered and threatened species since 1979 [3]. Animal trade donates a major role in biodiversity loss [4]. Reptile becomes one of the most hunted and traded animals [5] for medicines [6], foods [7], pets to some Asian countries [8], and also crafts in local or Europe industry [9]. A snapshot study was applied to reveal and analyze the actual trading problems, as was done on the bird trade [10] and Pangolin [11]. The purpose of this

\footnotetext{
Correspondence address:

Nia Kurniawan

Email : wawan@ub.ac.id

Address : Biology Departement,Brawijaya University, Malang, Indonesia. Veteran Street. ZIP.65113
}

research is to reveal the preparation procces of reptiles in the wholesaler and the flow of illegal trade through deep interview and observation in Kebumen Regency, Central Java, Indonesia.

\section{MATERIAL AND METHOD}

Survey was conducted on October 7-10 ${ }^{\text {th }} 2015$ in Kebumen Regency, Central Java. Observation was conducted in two stages. First, the flows of animal trade were observed according to the information from the local poacher in Wonosobo, Central Java. The trade flows were headed to the biggest wholesaler in Kebumen, and probably also the biggest wholesaler both in south and center of Central Java. Data of species, number, price, usage, and the customer of these reptiles were also collected during the survey. Deep and face to face interview were applied to reveal the transaction that were not obtained during survey. The interview's topic including: transaction before and after sending the supply to wholesaler, the largest supply season, sources of supply, earnings, and the preparation of the reptile products. The supply numbers were also collected from informant's narrative and receipt records.

\section{RESULT AND DISCUSSION \\ Supplies composition and source}

Supplies were recorded weekly from its surrounding area, especially Kebumen and Wonosobo (see table 1). Occasional supplies were recorded to be obtained from Banjarnegara, Purworejo, and Purwokerto. 
Reticulated python and tokay were supplied regularly in alive condition. Reticulated python were supplied from Kebumen and Wonosobo, both bred or captured from the wild. Rainy season (November-April) becomes the peak of the supply arrival. During that period, hundreds or even thousands supplies of chinese ratsnake and tokay arrived, although unfortunately it could not confirmed whether the recorded data was the fixed number or not in every peak season. The other species were also increasing in number during the rainy season, such as freshwater turtle, softshell turtle, and other snakes. The transition between dry to rainy season is the best hunting time for chinese ratsnake, as it's the best season for hunting [12].

As much as 289 reptiles were observed to be traded in various conditions (see table 2). Supplies were sorted according to species, and further treatment will differ according to the species. Most chinese ratsnake were slaughtered, gutted, washed, and stacked in a tin trays. Monitor lizards and tokays were drowned to death and then gutted (monitor lizard's skin was also removed). The flesh was dried by two steps: oven-baking and sun-drying. The oven space was limited, so the fleshes would be kept in the refrigerator first. Monitor lizard flesh was not dried because most of it will be consumed as food or traditional medicine, which was not needed further treatment. Pythons were slaughtered and skinned. The skin was then sundried and ready to be sold as textile material, art or crafts. According to the Poacher, four reticulated python was sold for USD 2.35/individual due to their length (1.5 meters), while the wholesaler bought it for USD $0.75 /$ individual as profit. The snakes should be cared for 2-3 years until it reaches a proper length to be skinned, and can be sold for USD 74.96. Reticulated phyton were also sold alive as pet for USD 2.35/individual. Wholesaler tend to focused on achieving the best price by seeing wider market range and offer the reptiles to hobbyist and pet enthusiast. In fact, the minimum price offered by trader was higher than the standard price set by the government (see table 2). It represents the increase of economic value due to the limited number of supply that can be obtained.

\section{Wholesaler's trading web}

Wholesalers are one of the economic nodes that support the village-scale economy independently. They create various local and inter-district links worth thousands of dollars, ranging from the lowest hunters to bigger exporters (Figure 1). The available stock that is predicted to be sold out at 1 day worth approximately USD 433.79-584.8. In this case, wholesalers could collect at least USD 1301417544 in a month, even more than that amount, considering the survey conducted in dry season, which is known to contribute a very minimum supply.

People involved in reptile's trading form a cooperation network (see figure 1) and wholesalers play an important role in becoming the trade nodes. Wholesalers, who have a marketing and export license from BKSDA (Natural Resources Conservation Agency), will get a quota set by the government, so the trappers will collect reptiles according to their allocations. Generally, the trappers sell their captured animals directly to the wholesaler, or so called as dealer, who will distribute it to the leather craftsmen or to the registered exporters. But there are also situations where the trappers transact directly with the craftsmen or exporters [13]. Auliya [14] described that wholesalers usually have a role in preparing the initial products prior to export activities or further utilization. Basically, wholesalers have a strategic position as they can raise the price of reptile's products significantly. Siregar [15] revealed that major wholesaler or even exporters always monitor the development of the world market, so they can inform to the minor collectors about the prevailing prices. Even so, the price range in each level of wholesaler is quite varied.

Siregar [15] described that the snake skin's trading channel involves four parties: snake trappers, minor wholesalers, major wholesalers, and exporters. The differences in the wholesaler scale are affected by their different scale and collection system. Based on Auliya [14], one reptile's wholesaler can have 20 trappers/hunters. However, Semiadi and Sidik [2] explained that people involved in reptile's trading consist of trappers, regional wholesalers, agents, sub-agents, and retailers, both permanent and non-permanent.

\section{The threatened species}

The results of snapshot approach revealed two main species that are traded in large numbers: Chinese Ratsnake and Reticulated Python. Chinese ratsnake were accepted by the wholesaler if it length reachs $100 \mathrm{~cm}$ or more, although authors also found shorter snakes in the 
trade. Female ratsnake considered as mature when its length reachs $130-140 \mathrm{~cm}$ [14], which means ratsnake poaching could reduce the regeneration rate of its population due to the capturing activities before it reaches sexual maturity. Chinese consumes ratsnake, therefore the demand of this species throughout the year is considered as high [16]. In this case, Indonesia becomes their highest supplier, with 30-60 tons of flesh a year, and also 50-100 thousand of snake bile [14], or about 332.085 snakes a year [17]. Kebumen's wholesaler could receive up to 1.233 snake per year or 3-5 per week. Unfortunately, there's no gender record before the snake was slaughtered. Every python was only measured by length (>210 cm, total length) in order to be skinned. This act threatens the wild population due to the wild harvesting [18].

Reticulated phyton is known to be traded on a large scale, either in our findings in Kebumen or other area in North Sumatra [7, 8] and Central Kalimantan [18]. Python also becomes one of the most exploited species of snake in Southeastern Asia. A rough estimation explains 340.000 phyton's skins were exported to Europe every year, which originated mainly from Indonesia and Malaysia [9]. In addition to that problems, reticulated python population growth is hard to be monitored and maintained [1] and is threatened by long term poaching activity $[1,19]$. This particular estimation can be observed in the destruction of Cod fish (Gadus morhua) which is exploited due to its large population and considered to be sufficient to continually be exploited. The exploitation causes a domino effect which affects the economic and social aspects [20]. Further effect for drastic population reduction would affect the wholesaler more than the poacher itself [2]. Meanwhile, 19.640 wholesalers in Indonesia depends on the continuity of supplies, as it is the only job for them [21]. Beside that, a huge gap occurs between earning profit of wholesaler and international consumer level [9]. This means that high exploitation happened in rural area is not balanced by innovation or further processes, which could turn raw material into products to raise the supply quality.

Our research is expected to support the susceptibility of reptile's wild population against poaching and trading. These fact is also worsen by the difficulties in monitoring the wild population status and land conversion [22]. In other side, the population number reduction isn't balanced with the exploration of reptile benefits, especially as food and medicine [23] and genetic richness [22]. Authors suggest an addition in quota criteria which enacted in the official wholesaler and reptile's trading institution that regulates quantity, total length, and gender of the captured-reptiles. Hopefully, this can help governments and researchers to collect information about the habitat conditions and population size [22]. In addition, the development of genetic conservation and database of tissue and blood samples were also required in the wholesaler level to conduct an efficient and systematic review and evaluation regarding the species status [24].

\section{CONCLUSION}

The processes that happened in the wholesaler level is differed by further needs of the reptiles, whether it utilizes as food, medicine, pet, or craft. Chinese ratsnake and reticulated python became contributed as the two biggest supply that traded and exported mainly to European and Asian countries. The high demand and high exploitation rates became the main things that threatened the wild population of animal and environmental balance.

\section{ACKNOWLEDGEMENT}

Authors would like to thanks to all informants in Wonosobo and Kebumen. Authors also would like to thanks to PEER-USAID which funded the experimental cost. Lastly, a big appreciation to Mr.Sua for accompanying the authors on field.

\section{REFERENCES}

[1] Natusch, D.J.D., J.A. Lyons, Mumpuni, A. Riyanto, R. Shine. 2016. Jungle Giants: Assessing Sustainable Harvesting in a Difficult-to-Survey Species (Python reticulatus). PLOS ONE 11(7): e0158397. doi:10.1371/journal.pone.0158397.

[2] Semiadi, G., I. Sidik. 2011. Karakteristik penangkapan ular di wilayah Sumatra Utara. Biota 16(2): 206-213.

[3] Warta Bea Cukai. 2015. Majalah warta bea cukai. 47: 7. Subdirektorat humas dan penyuluhan Direktorat penerimaan dan peraturan kepabeanan dan cukai.

[4] Engler, M., R. Parry-Jones. 2007. Opportunity or threat: The role of the European Union in global wildlife trade. TRAFFIC Europe. Brrussels.

[5] Sheperd, C.R., V. Nijman. 2007. An overview of the regulation of the freshwater turtle 
and tortoise pet trade in Jakarta, Indonesia. TRAFFIC Southeast Asia. Petaling.

[6] Hamdani, R., D.H. Tjong, and H. Herwina. 2013. Potensi Herpetofauna Dalam Pengobatan Tradisional di Sumatera Barat. J. Bio. UA. 2(2): 110-117.

[7] Shine, R., Ambariyanto, P.S. Harlow, and Mumpuni. 1999. Reticulated Pythons in Sumatra: Biology, Harvesting and Sustainability. Biological Conservation. 87 (3): 349-357.

[8] Natusch, D.D., and J. Lyons. 2012. Exploited for pets: the harvest and trade of amphibians and reptiles from Indonesian New Guinea. Biodiversity Conservation 21:2899-2911.

[9] Kasterine, A., R. Arbeid, O. Caillabet, D. Natusch. 2012. The Trade in South-East Asian Python Skins. International Trade Centre (ITC). Geneva.

[10] Chng, S.C.L., J.A. Eaton. 2016. Snapshot of an on-going trade: an inventory of birds for sale in Chatuchak weekend market, Bangkok, Thailand. Birdingasia 25: 24-29.

[11] Zhang, M., G. Ana, Q. Tao, Q. Ruichang, and Vincent N. 2017. Illegal Pangoling trade in northernmost Myanmar and its links to India and China. Global Ecology and Conservaron 10:23-31.

[12] Sidik, I. 2006. Analisis Isi Perut dan Ukuran Tubuh Ular Jali (Ptyas mucosus). Zoo Indonesia 15(2): 121-127.

[13] Soehartono, T. and A. Mardiastuti, 2002. CITES Implementation in Indonesia. Nagao Natural Environment Foundation. Jakarta.

[14] Auliya, M. 2010. Conservation status and impact of trade on the oriental rat snake Ptyas mucosa in Java, Indonesia. TRAFFIC Southeast Asia. Selangor.

[15] Siregar, J. 2012. Upaya Pelestarian Pemanfaatan Ular Sanca Batik (Python reticulatus) dan Ular Sanca Darah merah (Python brongersmai) ditinjau dari Aspek Penangkapan dan Pemasarannya di Provinsi Sumatra Utara. Thesis. Sekolah Pascasarjana IPB.

[16] Lee, K.S., M.W.N. Lau, B.P.L. Chan. 2004. Wild Animal Trade Monitoring In Selected Markets in Guangzhou and Shenzhen, South China 2000-2003. AJL Design Ltd. Hong Kong.

[17] Kusrini, M.D., A. Mardiastuti, T. Harvey (Eds). 2003. Konservasi amfibi dan reptil di Indonesia. Proceeding of Seminar Hasil
Penelitian Departemen Konservasi Sumberdaya Hutan. Bogor.

[18] Wardhani, S.E. 2012. Tata niaga, karakteristik habitat dan parameter demografi sanca batik (Python reticulatus Scheider 1801) yang dipanen di Propinsi Kalimantan Tengah. Thesis. Sekolah Pascasarjana IPB. Bogor.

[19] Conover, M.R. 2001. Effect of hunting and trapping on wildlife damage. Wildlife society bulletin 29(2): 521-532. http://www.jstor.org/stable/3784176.

[20] Meng, K.C., K.L. Oremus, S.D. Gaines. 2016. New England Cod Collapse and the Climate. PloS ONE 11(7): e0158487. doi:10.1371/journal. pone.0158487.

[21] Ministry of Forestry. 2011. Country report of Indonesia: Snake trade and conservation. Ministry of forestry. Jakarta.

[22] Iskandar, D.T., W.R. Erdelen. 2006. Conservation of amphibians and reptiles in Indonesia: Issues and problems. Amphibian and Reptil Conservation 4(1):60-87.

[23] Afriyansyah, B., N.A. Hidayati, H. Aprizan. 2015. Pemanfaatan hewan sebagai obat tradisional oleh etnik Lom di Bangka. Jurnal Ekotonia 5(1): 8-18.

[24] Shaney, K.J., E. Wostl, A. Hamidy, N. Kurniawan, M.B. Harvey, and E.N. Smith. 2016. Conservation challenges regarding species status assessments in biogeographically complex regions: examples from overexploited reptiles of Indonesia. Oryx.

[25] Litbang Menlhk. 2017. Peraturan Pemerintah no.86 MENLHK tahun 2016 tentang penetapan harga patokan tumbuhan dan satwa liar di dalam dan diluar negeri. Accessed on August 8th, 2017. http://fordamof.org/index.php/content/undang_undan g/kategori/133/10 
Table 1. Supply source in wholesaler. Comparison of reported mean regular or incidental supply based on interview and transaction receipts in October 2015 (some of data was come from July and August). Suppliers were categorized as reguler if they give weekly supplies and incidental if they give unpredictable supplies.

\begin{tabular}{lccl}
\hline & \multicolumn{3}{c}{ Supply } \\
\hline & Regular & Incidental & Type of supply \\
Kebumen & 80,61 & 99,25 & Snakes, tokay, monitor lizard, turtles (also softshell turtle) \\
Wonosobo & 88,5 & - & Snakes, tokay, monitor lizard, turtles (also softshell turtle) \\
Cilacap & 89,5 & - & Snakes and turtles \\
Banjarnegara & - & 63 & Tokay \\
Purworejo & - & 79 & Tokay and snakes \\
Purwokerto & 31 & 8,33 & Geckos, snakes, and turtles \\
\hline
\end{tabular}

Table 2. Total of reported supply at on-going trade (USD1=IDR13320; August $7^{\text {th }}, 2017$ )

\begin{tabular}{|c|c|c|c|}
\hline English name & Stock/condition & $\begin{array}{l}\text { Lowest-highest price in } \\
\text { USD/ sale unit }\end{array}$ & Standard price* \\
\hline King Korros Ptyas carinata & 4/life & $1.69-5.62 /$ ind & $1.65 /$ ind \\
\hline Javan Spitting Cobra Naja sputatrix & 34/life & $1.5-2.25 /$ ind & $1.28 /$ ind \\
\hline $\begin{array}{l}\text { Red Tailed Racer Gonyosoma } \\
\text { oxychepala }\end{array}$ & 1/life & $1.12-1.87 /$ Ind & $1.65 /$ ind \\
\hline $\begin{array}{c}\text { Copper-head Trinket Snake } \\
\text { Coelagnathus radiatus }\end{array}$ & 1/life & 7.5-9.37/ind & 1.65/ind \\
\hline Indian Rat Snake Ptyas mucossa & 3/life & 1.12-1.5/ind & 1.65/ind \\
\hline $\begin{array}{c}\text { Gold-ringed cat snake Boiga } \\
\text { dendrophila }\end{array}$ & 1/life & $1.87-3 /$ ind & 1.65/ind \\
\hline $\begin{array}{l}\text { Reticulated python Malayopython } \\
\text { reticulatus }\end{array}$ & 2/Peel;23/life & $\begin{array}{c}1.12-1.887 / \mathrm{kg} \\
; 74,96 / \text { Peel; } 2.25- \\
2.62 / \text { ind }\end{array}$ & 2.03/ind \\
\hline Asian water monitor Varanus salvator & 2/dried-flesh;1/life & $1.12-1.87 / \mathrm{kg} ; 3.75-6 /$ ind & 1.28/ind \\
\hline Chinese ratsnake Ptyas korros & $\begin{array}{l}\text { 200/dried-flesh; } \\
\text { 8/freezed }\end{array}$ & $0.6-0.9 / \mathrm{kg}$ & $1.65 /$ ind \\
\hline $\begin{array}{l}\text { Malayan softshell turtle Dogania } \\
\text { subplana }\end{array}$ & 4/life & $\begin{array}{l}\text { 7.5-14.99/ind (depend on } \\
\text { size) }\end{array}$ & $1.5 /$ ind \\
\hline
\end{tabular}

*Based on Government Law No. 86 MENLHK, 2016 about plant and animal price standards in national and foreign market [25] 
Figure 1. Schematic of reptile supply chains operating in wholesaler

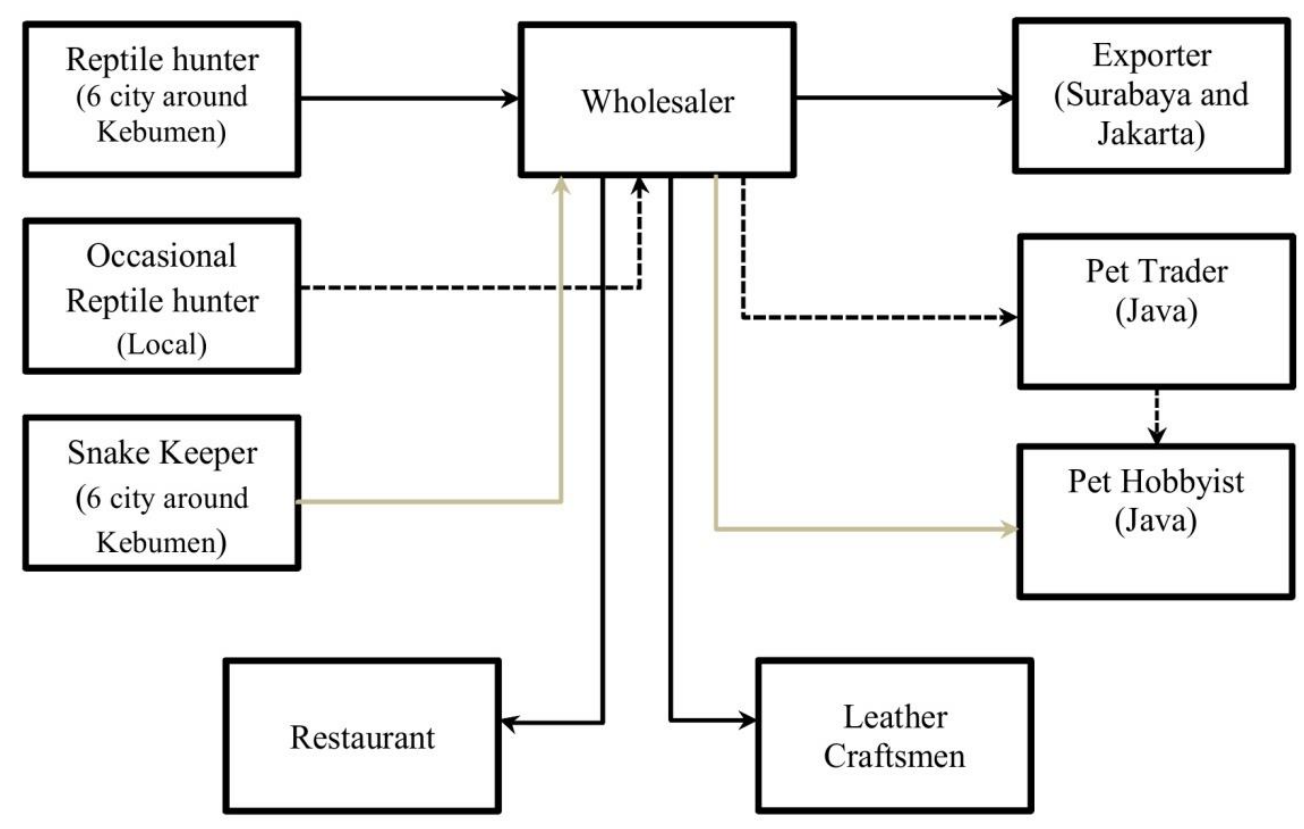

LEGEND

High volume, low value trade Low volume, high value trade

Low volume and/or occasional trade in each supply 